\title{
Dekonstruksie en Bybelse hermeneutiek
}

\author{
N J S Steenekamp \& A G van Aarde \\ Universiteit van Pretoria
}

\begin{abstract}
Deconstruction and biblical hermeneutics
\end{abstract}

The purpose of this article is to evaluate deconstruction as a postmodern philosophical viewpoint in relation to biblical hermeneutics as a theological interpretation method. A short exposition of postmodernity is given to emphasise deconstruction's aim of deconstructing traditional views on texts and metaphysics. This leads to intertextual reading which is in opposition to the textual reading of biblical hermeneutics. The consequences of deconstruction are finally evaluated in relation to the methods of Redaktionsgeschichte and the historische Jesus Forschung.

\section{VRAAGSTEL.IING}

In die tradisionele Bybelse hermeneutiek word die onderskeid dikwels getref tussen 'metode' en 'benaderingswyse'. So byvoorbeeld is die historiese kritiek 'n benaderingswyse in Bybelinterpretasie en Redaktionsgeschichte 'n bepaalde metode wat op 'n histories-kritiese wyse tekste ontleed. Dekonstruksie is egter nie 'n metode nie; dit verteenwoordig 'n postmoderne benaderingswyse wat nie net op die tekswetenskap as sodanig betrekking het nie, maar op epistemologie in die algemeen. Epistemologie het te doen met die vraag hoe ons tot kennis kom. Dwarsdeur die Moderne Era, wat dikwels die Cartesiaans-Newtoniaans-Kantiaanse era genoem word, het epistemologie neergekom op 'n rasioneel-beheersde verhouding tussen die subjek van kennis en die objek van kennis. Hierdie 'objek' is op grond van 'n lank gewortelde Westerse tradisie deur middel van 'n logosentrerende metafisiese benaderingswyse bestudeer.

\footnotetext{
- Ingedien en aanvaar as dee! van die vereistes vir die BD-graad, Fakulteit Teologie (Afd A), Universiteit van Pretoria, onder leiding van prof dr A G van Aarde.
} 
Wat die semantiek betref, het hierdie epistemologiese benadering daarop neergekom dat betekenis gedefinieer is na aanleiding van die sogenoemde referensie van 'n taalteken (designatum/verwyser) wat na 'n saak (denotatum/verwysde) verwys. Die Louw-Nida semantiese woordeboek van die Grieks van die Nuwe Testament is 'n produk van 'n sodanige moderne semantiek. Die postmoderne, dekonstruktiewe 'grammatologie' vooronderstel egter 'n radikaal ander semantiese beginsel wat ook 'n totaal nuwe leesstrategie meegebring het. Hierdie ondersoek vra eerstens die vraag na die aard van hierdie leesstrategie en tweedens watter implikasies dit het vir enersyds een van die tradisioneel histories-krities eksegetiese metodes, te wete die Redaktionsgeschichte, en andersyds die historiese Jesus-vraagstelling. Die program van ondersoek val soos volg uiteen: 'n Kort opsomming van die algemene kenmerke van die Postmoderne Tyd word gegee. Dit dien as oriëntasie om die denkmilieu bekend te stel waarbinne dekonstruksie tuis is. Die posisie van dekonstruksie binne hierdie klimaat word vervolgens bespreek.

In hierdie bespreking word nie gebruik gemaak van die oorspronklike werke van Jacques Derrida nie. Derrida word beskou as die vader van die dekonstruktiewe benaderingswyse. Die filosofiese agtergrond van sy werk is omvangryk en diepliggend. 'n Deeglike bestudering daarvan sal 'n baie groter bestek as die omvang van hierdie studie vereis. Derrida se skryfstyl is ook 'baie moeilik': Hy gebruik sy woorde met groot omsigtigheid. So slaag hy daarin om die 'betekenis' van woorde op 'n 'speelse' wyse in te span, sodat dit deel van sy dekonstruktiewe leesstrategie word. Baie fyn nuanses in betekenis, of liewer in verplaaste betekenis', kom so na vore. Deur die aanwending van hierdie nuanses in betekenis, ontbloot Derrida die onderbou van die Weste se tradisionele intellektuele tradisie(s). Hierdie 'taalspel' word natuurlik moeilik in vertalings weergegee en dus word heelwat van die terme wat Derrida gebruik, as tegniese terme getranskribeer. Daar is aanbevole sekondêre werke oor Derrida se geskrifte beskikbaar. Twee boeke van Jonathan Culler, On deconstruction theory and criticism after structuralism en The pursuit of signs: Semiotics, literature, deconstruction, is in hierdie studie gebruik om tot 'n algemene verstaan van dekonstruksie te kom. Daarby is ook Harold Bloom se Deconstruction and criticism geraadpleeg. Hierdie werke verskaf almal 'n goeie inleiding in die hermeneutiese relevansie van dekonstruksie as 'n postmoderne filosofie. Die verhouding waarin hierdie filosofie tot die literatuurteorie staan, word in hierdie werke deeglik uiteengesit. Daarbenewens word die gevolge van dekonstruksie vir die metafisika daarin verwoord. Hierdie saak word egter nie op sigself in die onderhawige studie hanteer nie. Die artikels waarna daar in die studie verwys word en wat handel oor die postmoderne tendense in die teologie, is hoofsaaklik geskryf deur teoloë en is ook in Bybelwetenskaplike publikasies gepubliseer. Die vraagstelling in 
die artikels is reeds gereduseer tot die terrein waartoe hierdie artikel hom bepaal: die hermeneutiese konsekwensies van dekonstruksie in die teologie. Die implikasie van dekonstruksie met betrekking tot die Redaktionsgeschichte en die historiese Jesus-navorsing word laastens bespreek. Hier word in die besonder verwys na die artikels van W S Vorster en $\mathbf{S}$ Fowl. In beide die gevalle word die onderskeie terreine wat hulle bespreek, met dekonstruksie in verband gebring.

\section{POSTMODERNITEIT}

Die twintigste-eeuse Westerling is 'n na-Aufklärung-mens wat die werklikheid en sy plek daarin rasioneel analiseer en beskryf. Ook sy eie wêreld en tyd word as objek van studie gesien. Die geskiedenis van die Westerse mens kan ingedeel word in stadia in terme waarvan 'n rasionele besinning oor sy agtergrond moontlik is. So kan ons dink aan die 'Westerse jaartelling' wat selfs die universele datumverwysing geword het. Meer nog: Binne die post-Christus era is daar sprake van die Middeleeue, die Moderne en die Postmoderne stadia. Spesifieke daterings vir wanneer hierdie stadia sou begin en eindig, is moeilik vasstelbaar. Dit berus hoofsaaklik op retrospektiewe evaluasie. Verder blyk 'n grens makliker getrek te word tussen stadia wat eeue van ons af in die verlede lê as wat tans as afbakenings geld. Die tyơ waarin ons ons bevind word reeds deur baie denkers beskou as die Postmoderne. Tog meen andere dat ons ons steeds in die Moderne tyd bevind.

Enkele eienskappe van postmoderniteit kan kortliks soos volg weergegee word: Postmoderniteit word deur negatiwiteit gekenmerk. 'Die Weste se fondamente is stukkend. 'n Mens moet baie naïef wees om te glo dat die kerk nog 'n diepgaande bydrae tot ware religieusiteit lewer' (De Beer 1985:2). Hoewel 'negatiwiteit' as sodanig reeds baie lank die onderwerp van die filosofiese gesprek is, het dit eers deesdae simptomaties geword om van 'n negatiewe tydsgees te praat (Gouws 1988: 26). Tog kan hierdie negatiewe tydsgees positiewe bydraes vir die teologie en Bybelse hermeneutiek lewer. Postmoderniteit funksioneer as 'n 'holistiese paradigma wat ontologies beskryf kan word as monisties en epistemologies as interpretatief' (Van Aarde 1990:1). So gesien, veronderstel dit ' $n$ radikale breuk met die tradisionele Westerse wetenskapsbeskouing. Die tradisionele stof-gees-digotomie word naamlik opgehef, dit wil sê, die dualisme van die kenbare en die onkenbare word vervang met 'n monisme waar die twee sfere vervleg word. Ten tweede word die aard van wetenskap as 'n beskrywende aangeleentheid vervang met 'n interpretatiewe besigwees in die leefwèreld. Die 'waarheid' van 'n kontroleerbare bevinding word verruil vir die individuele persepsie en ervaring van waarheid en werklikheid. 


\section{DEKONSTRUKSIE AS 'N POSTMODERNE BENADERING}

Die postmoderne denkstruktuur mond uit in heelwat literatuurteoretiese werkwyses soos onder meer die resepsieteorie, dekonstruksie en feministiese kritiek (vgl Newton 1988:14). Dekonstruksie kan derhalwe nie as 'n eksegetiese metode beskou word nie. Dit is veel eerder 'n nuwe filosofiese werkwyse of ingesteldheid, 'n denkraamwerk van waaruit met betrekking tot die lees van 'n teks vertrek word. C S de Beer meld dat die tipe denke eintlik 'n ongerigte, ongeoriënteerde karakter het. Metode lê vrye denke aan bande. Dit is juis hierdie saak wat Derrida in navolging van Heidegger beklemtoon: Enige metode werk beperkend in op vrye denke. Die objektiverende karakter van denke maak selfs die syn tot objek en dwing daarna die werklikheid in 'n metode in. 'Die metode word 'n soort tegnologisering van denke' (De Beer 1986:439). Dekonstruksie wil dus nie metode wees nie, maar juis vrye denke wat gestimuleer word deur die teks se openheid tot die leser. Ter wille van 'n beter verstaan hiervan, gee ek vervolgens aandag aan 'n paar uitgangspunte in die dekonstruksie.

\subsection{Logosentrisme en Différance}

Logosentrisme is die ingesteldheid van Westerse denke dat 'betekenis' (logos) sentraal staan. 'Betekenis' het ' $n$ metafisiese status. Hierdie metafisiese status van 'betekenis' is die direkte gevolg van die denke van Plato. In sy ideëleer stel hy 'n wêreld voor waar die ware realiteit teenoor die aardse werklikheid manifesteer. Alles op aarde is bloot skaduwees van hierdie werklikheid, 'n blote voorbeeld van die korrekte idee. Daar is dus net een 'betekenis' of realiteit; alle aardse voorwerpe kan in mindere of meerdere mate daarmee vergelyk word. So is alle beddens byvoorbeeld namaaksels van een bed, die ware idee 'bed' (vgl Plato 1988:17). Die 'ware bed', ofte wel die korrekte betekenis van enige saak lê as metafisiese gegewene iewers agter ons werklikheid verskuil. Taal word slegs ingespan om 'betekenis' te probeer omskryf. 'Betekenis' staan met ander woorde onafhanklik van die taalspel (Newton 1988:147). Wat wanneer gesê word, kan hoogstens diesseitig vals, minder vals, of amper korrek wees. Die ware betekenis wat in sy metafisiese sfeer manifesteer, bly onaangeraak.

Gelukkig het 'spraak' deur middel van die denke die vermoë om tot 'n beter begrip - tot betekenis self - te kom. Waar 'spraak' gevoer word, heers die moontlikheid om tot begripsversmelting te kom, aangesien etlike moontlike betekenisse omskryf en geëvalueer kan word. 'Suiwer betekenis' word dan moontlik, aangesien daar 'n geslote temporele vlak is. Persone wat met mekaar in gesprek is, kan 'suiwer betekenis' daar en dan bepaal. Die opskrifstelling van hierdie betekenis waartoe 'spraak' gekom het, vind as sekondêre handeling plaas. 'Skrif' word bloot die 
tekens waarmee die taal en betekenis weergegee word. Die ware betekenis van dit waaroor die 'skrif' handel, lê iewers verskuil in 'n metavlak. Die vermoë om tot hierdie metavlak deur te dring, was die oogmerk van die strukturalisme. Deur die struktuur in taal te ontbloot, kan 'n metataal as verwysing geskep word in terme waarvan daar oor die 'ware betekenis' gepraat kan word (Hartin 1986:26). Die temporele geslotenheid van die gesprek kon dus so gesimuleer word. Die subjek (verwyser) en die objek (verwysde) word in dieselfde tydsvlak geslote gehou; die leser dring deur middel van die struktuur in dieselfde tydsvlak in en verwerf die 'korrekte betekenis'. So 'n taalhandeling kan dus as sinkroniese aktiwiteit beskou word. Dit het naamlik sy vastigheid as gevolg van 'n sekere verhouding van struktuur en betekenis in 'n bepaalde tyd.

Teen hierdie tipe logosentrisme is die dekonstruksie gekant. Dekonstruksie stel 'skrif' as primêr bo 'spraak'. In 'skrif' is die verwyser (subjek) altyd aktief en trek deur sy aktiwiteit 'n temporele vlak in die teks in. Die eenheid tussen subjek en objek kan nooit volledig wees soos in die logosentrisme, wat 'spraak' bo 'skrif' as vertrekpunt het nie. Volgens die dekonstruksie is die temporele vlak van 'n teks geopen. Elke leser in sy tyd en konteks versmelt met die teks om 'n nuwe betekenis te skep. Die betekenis van die teks word elke keer opnuut verplaas na 'n ander konteks. Derrida dui hierdie gebeure aan met die begrip différance. Dit is 'n term wat jets probeer weergee van die idee van die herhaalde 'uitstel' van die betekenis van tekens na 'n nuwe konteks wat telkens met betrekking tot die vorige 'verskil' (vg] Crossan 1982:35-39). Différance funksioneer as beskrywing van die 'onsekerheid' met betrekking tot die betekenis van taal en skrif. Die betekenis van 'n taalteken is altyd afhanklik van die tekens in sy direkte omgewing. Geen teken beskik inherent oor betekenis, soos die logosentriese vroeëre etimologiese benadering in die semantiek gemeen het nie. Die teken is self ook nie die voorwerp waarna verwys word soos daar in die strukturalistiese leesstrategieë gemeen word nie.

Met behulp van die beginsel van différance toon Derrida aan dat die aspek van die 'verwyser' in 'n taal nie beskou kan word as ondergeskik aan die aspek van die 'verwysde betekenis' nie. Tekens verwys nie na 'n realiteit buite hulleself nie, maar verwys na ander tekens in die taalhandeling waar 'skrif' voorrang bo 'spraak' het. Die aspek van metafisiese verwysing wat volgens die logosentrisme in die taalhandeling sou bestaan, is met ander woorde, volgens Derrida, afwesig. Taal is nie net 'n medium nie, dit is nie as 'fenomeen' sekondêr teenoor die kategorie 'idee' nie, maar bestaan outonoom omdat dit betekenis op sigself moet ontwikkel (Hunter 1987: 129). Derrida se beswaar teen die logosentrerende metafisika het betrekking op die absolute fondament van ons denke, die vals aanname dat taal tekenaar is van betekenis. Taal is sodoende die geleentheid ontneem om tot eie ontwikkeling te kom. 
Dekonstruksie wil ' $n$ kritiese posisie inneem teenoor die metafisika wat taal beheers het en wat die interpretasie van taal in die verlede gelei het. So is daar byvoorbeeld in die verlede geglo dat die lees van 'n gedig 'n luisterhandeling na 'n 'stem' is (nie noodwendig die digter s'n nie). Die gedig moes iets 'sè'. Verder het die illusie gegeld dat die digter se bedoeling met die gedig begryp word indien die gedig verstaan is.

Laastens moes die leser ook iets daarvan 'ervaar' dat sy kennis en insig verbreed is deur sy lees van die gedig. Hierdie bogenoemde drie vooronderstellings, wat ook vir ons as interpreteerders van die Bybelteks al te bekend lyk, kan 'an orthodoxy of understanding' genoem word (Hunter 1987:129). Dekonstruksie bevestig nie soos die strukturalisme hierdie ortodoksie nie. Dit ontken juis die metafisiese beginsels waarvolgens taal sou funksioneer. Dekonstruksie wys die sogenaamde abnormale gegewens in taalgebruik uit.

\subsection{Tekstualiteit en intertekstualiteit}

Wat die Bybelse hermeneutiek betref, meld Vorster dat die tradisionele bronnestudies in die Bybelwetenskappe nie as negatief beskou hoef te word nie. Hy beskou dit as die historiese voorlopers van die huidige intertekstuele benaderings. NuweTestamentici is so gewoond aan die werkwyse dat hulle as 't ware hulle eie bronne geskep/gesimuleer het (Vorster 1989:19). Ons dink hier byvoorbeeld aan die hipotetiese Q-bron. Sulke bronnestudies het ten doel gehad om aan te toon watter ander gekonstrueerde 'intertekste' op 'n bepaalde teks invloed uitgeoefen het. Dit is nie vergesog om hieruit af te lei dat die skrywer van die teks wat 'n ander teks as bron gebruik het, deur die skrywer van die bronteks beïnvloed is nie.

Hierdie benadering berus op ' $n$ spesifieke siening oor wat ' $n$ teks is. Tekste word normaalweg in die Nuwe-Testamentiese wetenskap beskou as eenhede wat as geskrewe teks produkte is van verskeie bronne, hetsy mondelinge of geskrewe bronne. Die hedendaagse dekonstruktiewe siening van tekstualiteit verskil egter van die bogenoemde beskouing. Kristeva, Barthes en vele ander beskou 'n teks as 'n herskrywing van vorige tekste, maar ook as reaksie teen vorige tekste (Vorster 1989: 20). ' $n$ Teks is dus 'n netwerk van tekens, gevul met die spore van vroeëre tekste. Die teks word nou gewysig van 'n eenheidstruktuur tot 'n sentrum met kante. Die kante ('edges') kan gesien word as die punte waar die teks 'haak' met ander tekste of verwysings. Die 'sentrum' is bloot die gedagte wat die teks wil uiter en nie noodwendig die sentrale teks of bedoelde betekenis van die teks nie. Veel eerder verteenwoordig die teks 'n 'netwerk van spore sonder begin of einde of middelpunt wat gedurig na ander tekste en dinge verwys' (Vorster 1987:384). Die teks word met ander woorde nie meer as 'n objek beskou nie. Lesers vind nie langer die betekenis 
van tekste in 'n teksinterne struktuur nie, maar in 'n netwerk van intertekstualiteit. Hierdie intertekstuele netwerk verwys na en het betrekking op elke aanhaling, maar ook op elke ander sin in die teks.

Die teks se 'verwysingsraamwerk' kan teoreties in enige ander relevante teks gevind word. Vorster (1989:21) wys op drie belangrike gevolgtrekkings wat op grond hiervan gemaak kan word. Ten eerste blyk dit duidelik dat die begrip 'teks' totaal gewysig is. Selfs die konsep 'boek' verander: 'n Boek verander 'totaal van status en word deel van 'n sisteem, interteks' (Vorster 1987:384). Tweedens blyk dat daar meer aandag geskenk sal moet word aan die teks se produksieproses as aan die bronne waaruit dit tot stand gekom het. Die leser moet dus bewus word van die intertekste wat in die relevante konteks aanwesig is. Laastens en voortvloeiend uit die voorafgaande kan die leser se rol in die leeshandeling nie meer buite rekening gelaat word nie. 'n 'Dekonstruktiewe intertekstuele leser' stel dus belang in die verskeidenheid tekste wat met 'n bepaalde teks verband hou en bring so 'n epistemologiese visie na vore wat verskil van byvoorbeeld 'n 'redaksie-historiese leser' se 'intertekstuele interpretasie'.

Die intertekstuele aktiwiteit in dekonstruksie antwoord positief op die oproep van Derrida om nie op 'n logosentrerend-metafisiese werkwyse te werk te gaan nie. Die betekenis word nie in die sentrum van 'n teks of in 'n metafisiese punt bo, onder, agter, voor, buite of binne die teks gesoek nie. Die intertekstuele aktiwiteit roep die dekonstruktiewe leser op tot 'n deelnemende betrokkenheid by die lees van die teks. Hy lees 'n teks met sy eie verwysingsraamwerk as interteks en kom dus op so 'n wyse tot besinning oor die teks voor hom. Die leser ken betekenisse toe aan die teks of fragmente daarvan. Intertekstualiteit bevestig met ander woorde dat geen teks selfgenoegsaam is of so funksioneer nie; dit dra nie self betekenis nie (Hunter 1987:131).

\subsection{Die dood van die outeur}

Die subjek (skrywer) verloor sy eie identiteit wanneer hy oor die kloof tussen 'praat' en 'skryf' tree; die identiteit van die spreker word opgehef. Die skrywer van 'n boek is vir die leser iemand wat voor die boek reeds daar was. Die skrywer word fisies die verlede van sy eie boek, die verlede van sy eie skryfhandeling. 'n Teks vorm 'n eenheid wat gegrond is op die doel van skrywe. Die doel van die skrywe van 'n werk is ook nie persoonlik van aard nie, maar word weer deur die teks en die aard daarvan bepaal. Die taal in die teks neem die spreekfunksie van die skrywer oor. Sy eie stem word stil. 'n Nuwe identiteit, die teks, word gevorm. Die teks se identiteit staan voorop. Die betekenis daarvan word telkens met elke nuwe leesakte oor en oor toegeken. Die teks word dus telkens hier en nou herskryf. Die uitspraak waar- 
toe ' $n$ teks die leser bring, is die enigste wat weer in tyd waarde het. Die leser se 'lewe' word gevul met hermeneutiese waarde - die skrywer daarenteen, word 'gedood'. Hierdie prosedure is in wese hermeneuties kontraproduktief.

\subsection{Dekonstruksie in aksie}

In 'n resensie van Derrida se boek The post card: From Socrates to Freud and beyond beskryf John Caputo die afdruk op die boek se voorblad. Dit is ' $n$ afbeelding van Sokrates wat die filosofiese teks op skrif stel wat Plato dikteer. Dis natuurlik 'n reëlregte ommekeer van die tradisie. Caputo (1990:22) maak die implikasie van die ommekeer deur middel van ' $n$ analogie eksplisiet. Hy beskou naamlik 'n skildery as tiperend van die oordrag van tradisie in die Weste. Na aanleiding van hierdie analogie toon hy dat die tekste wat ons het, nie sonder meer as ipsissima verba oorgelewer is nie. Die proses is heelwat meer ingewikkeld. In terme van die Bybel beteken Derrida se toepassing dat Jesus, soos Sokrates, die teks op skrif gestel het, terwyl die apostels en die dissipels, die apostoliese vaders en die vroeë kerk, soos Plato, aan Hom gesê het wat om te skryf! Wat Hy aangesê word om te skryf, is die gevolg van mondelinge tradisies en liturgiese praktyke wat ontvang en oorgelewer is. So gesien is Jesus se logia die produk van sy volgelinge! Hierdie Bybelse analogie is 'n puik voorbeeld van die ommekeer wat 'n dekonstruktiewe leeshandeling veronderstel. Jesus word die effek. Hy is, met ander woorde, nie vergelykbaar met die oorspronklike inhoud wat bewaar en oorgelewer word in klassieke terme nie. Hy word die nuwe inhoud wat deur sy volgelinge geskep word: 'The founder is founded' (Caputo 1990:22). Hierdie voorbeeld is ' $n$ radikale aanduiding van wat in die kerk en teologie reeds 'n geruime tyd plaasvind. In ons eksegese gee ons aandag aan die aard en plek van skrywe, die outeur en dies meer. Wat in werklikheid gebeur, is dat Jesus gesê word wat om te sê!

Vervolgens word aandag gegee aan die evaluering van die dekonstruktiewe leesstrategie in terme van die tradisionele Bybelse hermeneutiek.

\section{DIE IMPLIKASIE VAN DEKONSTRUKSIE VIR DIE REDAKTIONS- GESCHICHTE AS HISTORIES-KRITIESE METODE}

Sedert die werk van die Geneefse linguis, Ferdinand de Saussure, word daar in die moderne semantiek 'n onderskeid getref tussen taal as simbool en die objek wat daarmee beskryf word (vgl Van Aarde 1985:563). Hierdie verhouding tussen taal en objek staan bekend as ' $n$ referensiële verhouding. Die betekenis van die saak waarna die woord as taalsimbool verwys, is aan baie interpretasiemoontlikhede onderworpe. Hierdie veelvoud van betekenismoontlikhede staan as polisemie of polivalensie bekend. Op die terrein van die Bybelse hermeneutiek is daar in hierdie verband 'n 
wesenlike gevaar wat as 'referensie-dwaling' bekend staan: 'Met referensie-dwaling word enersyds die eksegetiese fout aangedui wanneer die hermeneut sonder meer vanuit die wêreld van die teks wil beweeg na die historiese sosio-kulturele en godsdienstige konteks in die werklike wêreld waarop die teks betrekking het, en andersyds die teologiese fout om te meen dat historisiteit die waarborg van die waarheid van die Skrif is' (Van Aarde 1985:563). Die vermyding van die referensie-dwaling hoef egter nie te lei tot 'n a-historiese teksinterpretasie nie. 'Dit is juis die voortbestaan en funksionering van 'n teks in sy buitetekstuele werklikheid, histories en teenswoordig, wat die hermeneutiese onderneming moontlik maak' (Van Aarde 1985:565). Met hierdie stelling word in die hermeneutiek die beskouing van die teks as sentrale en outonome entiteit erken.

Dekonstruksie het hierdie probleem in 'n nuwe kader geplaas deurdat die vraagstelling verbreed is om die epistemologiese agtergrond van sowel die skrywer as die van die huidige leser in aanmerking te neem. Dit het nie ten doel om, soos die tradisionele hermeneutiek, die historiese agtergrond van die skrywer of sy gemeenskap te rekonstrueer nie, maar juis om hulle denkwèreld bloot te lê. Volgens Derrida verdwyn die outeur agter sy teks omdat hy nie meer daarin te onderskei is nie (De Beer 1986:452). Dit beteken dat dekonstruksie die verwysing wat in tekste voorkom, hetsy deur aanhaling of glosse, opvolg. Dit vind plaas deur die sogenaamde intertekstuele leeshandeling. 'n Verwysing na 'n ander teks in die teks wat die objek van studie is, sal weer lei tot verdere verwysing na meer tekste, ensovoorts.

Derrida bring in hierdie verband die begrip 'afwesigheid van referensie' na vore. 'Afwesigheid van referensie' staan teenoor die tradisionele hermeneutiek se siening met betrekking tot verwysing. Die hermeneutiese beskouing van verwysing is dat alle verwysings dui op 'n ander wêreld, waarheid of 'god'. Die verwysing tree representatief op. Die verwysing praat van iets anders as die teks; dit praat van 'n werklikheid. Derrida verwerp hierdie siening en beskou 'verwysing' as bloot illustratief (De Beer 1986:457). 'Verwysing' plaas die leser wat 'buite' die teks probeer staan, intertekstueel tydelik binne die Umwelt van die teks as konkretisering van 'n stukkie werklikheid wat vir die skrywer bestaan het.

As gevolg van die afwesigheid van 'n wêreld waarna verwys word, omdat dit deur tekens voorgestel word, kan die verwysing nie bestaan nie en word dit die illustrasie van iets wat sou wees. Die leser skep nuwe betekenis vir die teks deur die verwysing as illustrasie by die teks te lees. Die verwysing as vaste punt wat sekerheid gee en wat 'verstaan' moontlik maak, ontbreek egter.

Die referensie-dwaling wat in die hermeneutiese verstaansraamwerke vermy moet word, word dus ook deur Derrida gedekonstrueer. Die referensie as fisiese of metafisiese vaste punt is afwesig. 
In terme van die tradisionele Bybelse hermeneutiek waarsku Van Aarde (1985: $568,571)$ teen 'misplaaste konkreetheid' sowel as 'affek-dwaling'. 'Misplaaste konkreetheid' steek kop uit indien die leser of hermeneut nie rekening hou met die historiese gaping tussen die ontstaantyd van die Bybel en die huidige tyd nie. Dié verskynsel is in die Middeleeue en selfs in die ontstaantyd van die Bybel aangetref. Dit vind plaas wanneer 'n skrywer of leser 'n vorige situasie ondeurdag in sy eie tyd laat afspeel. Die later periode kom in die skrifstelling of verduideliking na vore. As voorbeeld hiervan geld van die toesprake van Deuteronomium wat ontstaan het voor of tydens die Babiloniese ballingskap, maar in die boek funksioneer as toesprake van Moses. 'Affek-dwaling' kan ontstaan as gevolg van die oorbeklemtoning van die rol van die leser in die toekenning van betekenis van tekste. Affek-dwaling kom voor wanneer die bydrae van die skrywer of strukturele relasies in die teks so losgelaat word dat die teks se waarde bepaal word deur slegs die subjektiewe rol van die leser. Albei bogenoemde dwalings se gevaar lề in die eensydige beklemtoning van die subjektiwiteit van die leser. Die opskorting van die historiese gaping sal die gevolg he dat die Bybel op onkritiese wyse gebruik word. Dit kan dan selfs resultate toon wat onversoenbaar is met die beginsels van die Reformasie wat die lees van die Bybel in sy grondtale beklemtoon het (Van Aarde 1985:571).

'n Vraag wat nou na vore kom, is of dekonstruksie nie ook gebuk gaan onder die las van subjektiwisme en relatiwisme nie. Op die oog af lyk dit so omdat alle tekste intertekstueel gesag dra en daar ook nie geldige verwysings bestaan nie. Aan die ander kant bevraagteken egte dekonstruksie egter steeds die strukture waarbinne die denker staan. Dit beteken dat die enkeling nie goedsmoeds intertekstueel kan lees en waardes kan toeken aan verwysings binne die teks waarmee hy werk nie. Hy moet deurentyd ook sy eie denkwyse en handelinge onderwerp aan kritiese vraagstelling. Ook dit mag nie ' $n$ individuele aktiwiteit bly nie, maar die enkeling moet bereid wees om sy vooronderstellings in gesprek te ontbloot vir medegangers in die dekonstruktiewe arbeid. Slegs dan hoor ' $n$ mens in hierdie gesprek watter vooronderstellings verborge was in die tradisie waarin jy staan. 'One turns away from treating the various sayings of the traditions as propositions that have to be proved and defended. At the same time meaning remains the same in every reconstruction that one makes, thus avoiding the polarity of relativism' (Hartin 1986:34). Deur dekonstruksie kom die beoefenaar daarvan tot die 'ontmitologisering' van sy eie tradisie. Die Derridiaanse leser is in 'n sekere sin nie meer gebonde aan die begrippe 'relatiwiteit' en 'subjektiwiteit' nie, want dit is juis deel van die sisteem waarteen hy werk deur steeds daarin besig te wees.

Volgens Schneidau (1982:14) dwing 'n dekonstruktiewe lesing van die Bybel ons om onsself weer te sien in terme van 'n historiese verlede en nie in terme van die 
'changeless cosmic order' wat deur die logosentrerende metafisika geskep is nie. Dekonstruksie beklemtoon juis ons eie historisiteit en gebrek aan sekerheid teenoor 'sekere erfenis' wat deur die Griekse wêreld in ons denke ingedra is en tot uiting gekom het in die logosentrisme.

\section{DIE IMPLIKASIE VAN DEKONSTRUKSIE VIR DIE HISTORIESE JESUS-VRAAGSTUK}

Alle pogings om met betrekking tot die historiese Jesus-vraagstuk bydraes te lewer, het in 'n mindere of meerdere mate ernstige tekortkomings. Dit is volgens Fowl (1989:319) hoofsaaklik te wyte aan die feit dat navorsers hulle werk en resultate bou op die Jesus-logia. Die probleem is dat die Jesus-logia nie seker en vas is nie en dus nie 'n werklike goeie vertrekpunt vir studie bied nie. In die werk van Sanders Jesus and Judaism het hy as vertrekpunt sekere 'feite' oor Jesus se lewe wat as taamlik vas en seker beskou kan word. Hierdie is die feite wat na vore kom deur 'feitelike beriggewing'. Fowl meld agt feite wat as seker beskou kan word aangaande Jesus se lewe. Hieronder geld byvoorbeeld dat Hy gedoop is deur Johannes die Doper, dat Hy 'n Galileër was wat gepreek het en mense genees het en dat Hy twaalf dissipels geroep het. Verder is Jesus buite Jerusalem gekruisig deur die Romeinse owerheid en het sy volgelinge ná sy dood as 'n identifiseerbare groep voortbestaan. Hierdie 'feite' is niks anders as beriggewing nie. Hierdie werkwyse in die historiese Jesusondersoek hou sekere voordele in: Die waarheid van feite wat ter sprake is, berus nie op 'n teorie nie en die gebeure waaroor berig word, hoef nie aan 'n bepaalde voorafgaande verduideliking onderwerp te word nie.

Om Jesus Christus se lewe in terme van die Judaïsme van sy tyd te interpreteer, moet 'n mens verduidelikend te werk gaan. Die Judaistiese gebruike, norme en optrede word illustratief gebruik om die historiese Jesus te leer ken. Die oomblik wanneer Judaïsme die kriterium word vir uitsprake oor Jesus, word die navorsing aan 'n teorie ondergeskik gestel. Daar word weer in 'n singewende struktuur, 'n logosentriese metode, verval. Op dié wyse word die dekonstruktiewe werksaamhede aan bande gelê. Die gevolg van die 'dekonstruktiewe' werkwyse wat Fowl volg, is dat daar ' $n$ baie meer realistiese beeld van die Judaïsme van die eerste eeu geskep word. Dit kan bydra dat die historiese breuke wat ons vandag aanvoel, opgehef kan word. Die volgende kronologie verteenwoordig byvoorbeeld sulke breuke: Jesus onderrig een ding, word vir iets anders gekruisig en dan ken sy dissipels 'n bepaalde waarde aan sy dood toe. Dekonstruksie as werkwyse op dié terrein van die historiese Jesus-navorsing het volgens Fowl die vraagstelling gesuiwer. Die tradisionele gejaag na die oudste uitsprake oor Jesus en dié na die sogenaamde Jesus-logia is nou gewysig tot 'n perspektief wat ons dwing om te aanvaar dat die tradisionele historie- 
se Jesus-vraagstelling in werklikheid 'n verkeerde metode was. Ons wetenskaplike gereedskap kan nie die Jesus ontbloot waarna ons soek nie. Ons kan eerder die dekonstruktiewe weg bewandel en tot resultate kom wat ons oortuig dat 'n saak anders was as wat ons onsself voorgestel het (Fowl 1989:33).

\section{GEVOLGTREKKING}

'n Dekonstruktiewe leesstrategie kan nie as eksegetiese metode ontwerp word nie, aangesien die aard van die dekonstruktiewe werkwyse dit onmoontlik maak. Dekonstruksie dekonstrueer juis enige metode as sou 'betekenis' in vaste bane beweeg. 'Vaste' wetenskaplike metodes word ondersoek om die metafisiese vooronderstellings waarop dit berus, te ontbloot. Die vertrekpunt hiervan is negatief (vgl Leavey 1982:45-46), maar die resultaat kan vir die wetenskaplike, wat in elk geval krities ingestel behoort te wees, positief wees. Dit bevry die eksegeet nie net van die verabsolutering van 'n metode nie, maar ook van enige logies-positiwistiese wetenskaplike argumentvoering.

Die positiewe aspek wat dekonstruksie wel na vore bring, is dat dit 'n 'onmoontlike' antwoord in terme van 'n sekere metode moontlik maak omdat dit nie deur metode gebind word nie. Dit is moontlik omdat dekonstruksie in wese ingestel is op die geheel van moontlike antwoorde. Dit wil epistemologies geen moontlikheid buite rekening laat nie. Dekonstruksie kan selfs antwoorde wat in die logosentristiese denksisteme gevind word, steeds na waarde skat: '...Derrida can make no attempt to "replace" logocentrism' (Brink 1985:13). Dekonstruksie as nuwe ingesteldheid kan nie die eeue-oue tradisies ophef nie, maar omvat dit juis (Hunter 1982:138). Dekonstruksie as postmoderne leesstrategie hou ook 'n verdere implikasie in: Omdat dit nie bloot ' $n$ benadering is wat as deel van 'n eksegetiese metode ingespan of uitgelaat kan word nie, eis dit die leser op. Sy hele lewensbeskouing word gekenmerk deur die dekonstruktiewe leeshandeling. Alle sisteme, nie net tekste nie, word beskou in terme van 'intertekstuele' eenhede wat krake in hulle logosentriese fondamente blootlê. Die dekonstruktiewe leser moet hierdie 'krake' (metafisiese vooronderstellings) vind en dit heel deur radikale en kritiese deurdenking van sy eie metafisiese vooronderstellings. Dit verg 'n totale lewensbetrokkenheid.

Op die terrein van die Bybelse hermeneutiek en die teologie van die Nuwe Testament impliseer 'n dekonstruktiewe leeshandeling totaal alternatiewe denke. Naïef geredeneer, kan iemand meen dat 'n eksegetiese metode, soos die Redaktionsgeschichte, op sigself van die beginsel van intertekstualiteit uitgaan. Dit word immers gekruisstut deur die resultate van die Formgeschichte sowel as van die Traditionsgeschichte. Dit wil sê, 'n evangelie as literêre eindproduk word bestudeer vanuit 'n oënskynlike 'intertekstuele' vertrekpunt. Die redaktionsgeschichliche metode van 
eksegese let op die redaksionele verwerking van die bronne (ordening, byvoeging, weglating, stilistiese verwerking) deur 'n Evangelis, as eksponent van die eindfase van die oorleweringsproses van tradisies (kyk Van Aarde 1985:560-561, 566). Dit lyk dus of hier van 'n intertekstuele beginsel sprake is. Die beginsel waarmee die dekonstruksie werk, moet egter nie hiermee verwar word nie. Redaktionsgeschichte se doel is om die profiel van die Evangelis as skrywer te bepaal en sy intensie met sy skrywe te bepaal. Dekonstruksie gaan van die standpunt uit dat die skrywer 'dood' is en dat betekenis deurentyd verplaas word. 'n Mens kan as 't ware sê dat die skrywer se effek geleë is in dit wat die lesers van sy teks maak. Die leser self is deel van die beginsel van intertekstualiteit. Dit is dan juis op hierdie punt dat ons gesien het dat die tradisionele historiese Jesus-vraagstelling radikaal nuut onderneem word. Jesus is hiervolgens die 'effek' (kyk Fowl 1989). Hy word die inhoud wat sy volgelinge geskep het!

\section{Literatuurverwysings}

Bloom, H 1979. Deconstruction and criticism. London: Routledge \& Kegan Paul.

Brink, A P 1985. Transgressions: A quantum approach to literary deconstruction. $T L W 1 / 3,10-26$.

Caputo, J D \& Winquist, C E 1990. Derrida and the study of religion. Religious Studies Review 16/1, 19-25.

Crossan, J D 1982. Difference and divinity. Semeia 23, 29-41.

Culler, J 1981. The pursuit of signs: Semiotics, literature, deconstruction. London: Routledge \& Kegan Paul.

-- 1982. On deconstruction theory and criticism after structuralism. Ithaca: Cornell University Press.

De Beer, C S 1985. Represêntasie en dissêminasie. $T L W 1 / 3,1-9$.

--- 1986. Dekonstruktiewe lesing van 'n teks. HTS 42, 435-463.

Fowl, S 1989. Reconstructing and deconstructing the quest of the historical Jesus. SJTh 42, 319-333.

Gouws, T 1988. Die transskriptuele lees: Hiaat, haplografie en transskripsie in die poësie van Breytenbach, Krog en Cloete - 'n logolinguale lesing. DLitt-proefskrif, Potchefstroomse Universiteit vir $\mathrm{CHO}$.

Hartin, P J 1986. Deconstruction and theology. JTSA 54, 25-34.

Hunter, J H 1987. Deconstruction and Biblical texts. Neotestamentica 21, 125-140.

Leavey, J P 1982. Four protocols: Derrida, his deconstruction. Semeia 23, 42-58.

Newton, K M 1988. Twentieth-century literary theory. Londen: Macmillan. 
Pelser, G M M 1990. Hermeneutiek. Ongepubliseerde kernaantekeninge, Departement Nuwe-Testamentiese Wetenskap (Afd A), Universiteit van Pretoria.

Plato 1988. The Republic, Book X, in Maxwell-Mahon, W D (ed), Critical texts: Plato to the present day, 15-28. Kaapstad: Maskew Miller.

Schneidau, H N 1982. The word against the word: Derrida on textuality. Semeia 23, 5-28.

Van Aarde, A G 1985. Skrifgebruik: Hermeneutiese riglyne. HTS 41, 547-578.

-- 1990. Organismic holism in the light of the modernity-postmodernity debate. Paper delivered at the HSRC Conference on the Relevance of Theology in the 1990's, University of Stellenbosch, 20-23 September 1990.

Vorster, W S 1987. Op weg na 'n post-kritiese Nuwe-Testamentiese wetenskap. HTS 43, 374-394.

-.- 1989. Intertextuality and Redaktionsgeschichte, in Draisma, S (ed), Intertextuality in biblical writings, 15-26. Kampen: Kok. 